$\mathrm{DE}$

M E D I C I N A

T R O P I C A L

$\mathrm{DE}$

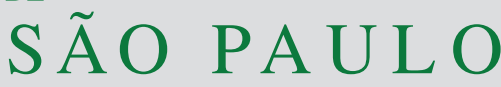

JOURNAL OF THE SÃO PAULO INSTITUTE OF TROPICAL MEDICINE

${ }^{1}$ Universidade de São Paulo, Faculdade de Medicina, Departamento de Pediatria, São Paulo, São Paulo, Brazil

'Universidade de São Paulo, Instituto de Medicina Tropical de São Paulo, Laboratório de Pesquisa Médica de Imunopatologia da Esquistossomose e Outras Parasitoses (LIM06), São Paulo, São Paulo, Brazil

3Universidade de São Paulo, Faculdade de Medicina, Departamento de Moléstias Infecciosas e Parasitárias, Núcleo de Medicina Tropical, São Paulo, São Paulo, Brazil

${ }^{4}$ Universidade de São Paulo, Escola de Enfermagem, Departamento de Enfermagem em Saúde Coletiva, São Paulo, São Paulo, Brazil

5Universidade de São Paulo, Faculdade de Medicina, Departamento de Moléstias Infecciosas e Parasitárias, Laboratório de Pesquisa Médica em Imunologia (LIM48), São Paulo, São Paulo, Brazil

Correspondence to: Francisco Oscar de Siqueira França

Universidade de São Paulo, Faculdade de Medicina, Departamento de Moléstias Infecciosas e Parasitárias, Laboratório de Pesquisa Médica em Imunologia (LIM48), Av. Dr. Enéas de Carvalho Aguiar, 470, Térreo, CEP 05403000, São Paulo, SP, Brazil

E-mail: fosfranca@usp.br

Received: 8 September 2020

Accepted: 9 September 2020

\section{Access to drinking water and sewage treatment in Brazil: a challenge for the control of waterborne infectious diseases}

\author{
Sao Paulo, September $7^{\text {th }}, 2020$
}

Dear Editor

Considering the worldwide advance of COVID-19 and the urgent need to alert the population to the main preventive measures, which include social distancing, the use of masks and hand washing, it is even more urgent for governments to take responsibility to provide conditions for the population to comply these recommendations.

It is noteworthy that the current pandemic caused by the new coronavirus (SARS-CoV-2) also reflects the reality of other Water, Sanitation, and Hygiene (WaSH)-related infections and diseases, which need access to drinking water, hygiene and proper waste disposal for their prevention and control ${ }^{1}$.

One in three people worldwide still do not have access to drinking water, two in five do not have adequate basic facilities to wash their hands with soap and water, and more than 673 million people do not have toilets or latrines ${ }^{2}$.

In Brazil, the recent disclosure of results from the Continuous National Household Sample Survey (PNAD), referring to basic sanitation conditions in 2019, demonstrates current unresolved needs ${ }^{3}$. Some indicators support this statement. The general water distribution network, which served $85.8 \%$ of households in 2016, has remained practically unchanged at $85.5 \%$ in 2019. In addition, regional distribution of the general water network is uneven, varying from $58.8 \%$ in the North region of the country to $92.3 \%$ in the Southeast ${ }^{3}$.

Analysis of the water sources and infrastructure used to supply Brazilian municipalities, shows that $31 \%$ of the population live in places of low water security, that is, they face rationing, collapse or warning in periods of drought; and $41 \%$ live in regions where production systems require expansion. Only $27 \%$ of the population live in municipalities where the supply was considered satisfactory. Water distribution across income brackets is very unequal, as $40 \%$ of the unserved population are in the 1 minimum wage or less income bracket ${ }^{4}$.

These regional inequalities are more intensely noticed when looking at the proportion of households with access to the general sewage system: in 2019, the North and Northeast regions of the country had the lowest coverage, with $27.4 \%$ and $47.2 \%$, respectively, whilst coverage in the Southeast region reached an estimated 88.9\%; and the South and Midwest regions had the same coverage of $68.7 \%{ }^{3}$.

Countrywide, $19.1 \%$ of households are connected to septic tanks but they are not connected to the general network; substantial regional variations are seen, with $42.9 \%$ of households in the North, $30.7 \%$ in the Northeast, and $5.5 \%$ in the Southeast using this modality of connection, thus corroborating the evident heterogeneity in the access to this essential service ${ }^{3}$.

Approximately 9 million households (12.6\%) had a ditch, rudimentary cesspit, river, lake or sea, in addition to other forms of waste disposal. In the North region, $29.6 \%$ of households (1.6 million) were in this condition, exceeding the estimated $27.4 \%$ of households connected to the general network ${ }^{3}$.

The relevance of sanitation infrastructure in the health-disease process was highlighted in a study on hospitalizations due waterborne diseases. It was estimated that, in 2015 , these diseases corresponded to $2.35 \%$ of all hospitalizations in 
Brazil, totaling $0.7 \%$ of total Unified Health System (SUS) spending on hospitalizations in that period ${ }^{5}$.

Overall, in 2015, diarrhea was estimated to be one of the main causes of death in all age groups (1.31 million), and one of the main causes of Disability-adjusted life years DALYs (71.59 million DALYs) due to its disproportionate impact on children under 5 years old. In general, rotavirus is the leading cause of death from this disease, followed by Shigella spp and Salmonella spp $^{6}$.

The World Health Organization reported that inadequate water, sanitation and hygiene conditions were responsible for 829,000 deaths from diarrhea in the world in $2016^{7}$.

Some waterborne diseases, such as gastroenteritis, are on the Brazilian list of primary care-sensitive conditions ${ }^{5}$. Hospitalizations for primary care-sensitive conditions represent potentially preventable conditions, which can reduce the risk of unnecessary hospitalizations and are a powerful indicator of primary care access and quality ${ }^{8}$.

Diseases that are still common in many regions of the world are associated with deficiencies in hygiene, sanitation and water supply. The group of diseases potentially transmitted by water contains both, viral (hepatitis A, $\mathrm{E}$ and $\mathrm{F}$, polio and viral diarrhea) and bacterial diseases (campylobacteriosis, cholera, legionellosis, leptospirosis, pathogenic E. coli, and salmonellosis such as typhoid and paratyphoid fever). In the latter group, it is important to highlight that, since 1817 , cholera has caused seven pandemics, the most recent being the one that started in 1961, responsible for epidemics in Haiti and the current devastating epidemic in Yemen ${ }^{9,10}$.

Protozoa also cause diseases through water transmission (amoebiasis, cryptosporidiosis, and giardiasis). Among helminthiasis, schistosomiasis stands out, an endemic disease directly related to the lack of basic sanitation in several regions of the country and still presenting with many natural foci for transmission of the disease ${ }^{11}$.

Water and sanitation are a world problem, resulting from rapid global urbanization, and finding solutions in large cities is particularly urgent. It is noteworthy that the majority of urban growth occurs in slums, in developing countries. The complexity of this issue is the reality for approximately one billion people (13\% of the world population) living in urban slums ${ }^{7,12,13}$.

When referring to the COVID-19 pandemic, it is essential to recognize that social distancing and frequent hand washing may not be possible for millions of people living in densely populated communities, with precarious housing conditions, and difficulties in the access to water and sewage treatment ${ }^{14}$.

Additionally there is the worsening water crisis in several regions of the world, as well as the evident ecological crisis, disasters and associated risks, such as the global warming in addition to the presence of polluting industries and technologies and their effects on water, soil, air and food, reducing the biodiversity and destroying ecosystems ${ }^{15}$.

The goal 6, one of the Sustainable Development Goals, proposes: "Ensuring the availability and sustainable management of water and sanitation for all"4. However, without an universal access to quality water and sewage treatment, which could allow hand hygiene minimally, we will not reduce morbity and mortality caused by waterborne diseases and in the future, we will be exposed again to other emerging pandemics, which will impact the quality of life of populations in the planet, and which could be avoided through basic actions such as an universal access to drinking water and sewage treatment.

Thus, according to Heller ${ }^{16}$, the recent approval by the federal government of the new Legal Framework for Basic Sanitation, Bill N $\mathrm{N}^{\circ} 4162 / 2019$, causes anxiety by breaking the fundamental principles of the current legal framework: universality, completeness, social control and the use of appropriate technologies.

Basic sanitation covers water supply, sanitation, drainage and rainwater management, urban cleaning and solid waste management. For Moraes ${ }^{17}$, an advisor to the National Observatory on the Rights to Water and Sanitation, the concession of public services to private companies and public-private partnerships (PPP) are already permitted by Laws 8,987/1995 and 11,079/2004, but this new Law $4162 / 2019$ substantially favors the private sector, whose only interest in the water supply and sewage sectors is where it can make the most profit. It also highlights that one of the most impactful changes in this law is to remove the autonomy of States and municipalities in hiring companies to distribute water and take care of the solid waste. In addition, this new law does not serve rural regions and, therefore, does not contribute to universalization ${ }^{17}$.

The challenge imposed by the COVID-19 pandemic highlights the urgency of establishing public policies aimed at reducing social inequalities and providing access to basic conditions that guarantee quality of life and health, as the 1988 Brazilian Constitution establishes that health is a right for all and a duty of the State.

The already precarious access for the most vulnerable populations to health services has been aggravated by the recent neoliberal measures that have worsened some health indicators, such as the increase in infant mortality in all but the Southern region of the country; and the increase in infant mortality from preventable causes, such as diarrhea ${ }^{18}$.

In July 2010, the UN General Assembly recognized, for the first time, in Resolution 64/292, the right to water and 
sanitation, admitting that drinking water and sanitation are essential for the accomplishment of all human rights ${ }^{19,20}$.

Access to drinking water and sewage treatment is a response to the pressing need to consider health-disease as a process that goes beyond merely a biological concept, but which is, above all, socially determined. Overcoming social inequalities requires public policies fundamentally oriented to reach the largest portion of social groups that, historically, and particularly in recent years, have been deprived of the social rights that ensure citizenship.

Filumena Maria da Silva Gomes ${ }^{\circledR 1}$ Maria Cristina Carvalho do Espírito Santo ${ }^{\circledR 2}$ Ronaldo César Borges Gryschek ${ }^{\circledR 2,3}$ Maria Rita Bertolozzi ${ }^{\circledR} 4$ Francisco Oscar de Siqueira França ${ }^{\circledR 3,5}$

\section{REFERENCES}

1. World Health Organization. Safer water, better health. Geneva: WHO; 2019. [cited 2020 Sep 9]. Available from: https://apps. who.int/iris/bitstream/handle/10665/329905/9789241516891eng.pdf?ua=1

2. United Nations. Sustainable Development Goals. Goal 6: ensure access to water and sanitation for all. [cited 2020 Sep 9]. Available from: https://www.un.org/sustainabledevelopment/ water-and-sanitation/

3. Instituto Brasileiro de Geografia e Estatística. Pesquisa Nacional por Amostra de Domicílios Contínua. Características gerais dos domicílios e dos moradores 2019. Brasil: IBGE; 2020. [cited 2020 Sep 9]. Available from: https://biblioteca.ibge.gov.br/ visualizacao/livros/liv101707_informativo.pdf

4. Brasil. Agência Nacional de Águas. ODS 6 no Brasil: visão da ANA sobre os indicadores. Brasília: ANA; 2019. [cited 2020 Sep 9]. Available from: https://www.ana.gov.br/acesso-ainformacao/institucional/publicacoes/ods6/ods6.pdf

5. Paiva RF, Souza MF. Associação entre condições socioeconômicas, sanitárias e de atenção básica e a morbidade hospitalar por doenças de veiculação hídrica no Brasil. Cad Saude Publica. 2018;34:e00017316.

6. Troeger C, Forouzanfar M, Rao PC, Khalil I, Brown A, Reiner Jr $\mathrm{RC}$, et al. Estimates of global, regional, and national morbidity, mortality, and aetiologies of diarrhoeal diseases: a systematic analysis for the Global Burden of Disease Study 2015. Lancet Infect Dis. 2017;17:909-48.

7. World Health Organization. Integrating health in urban and territorial planning: a sourcebook. Geneva: WHO; 2020. [cited 2020 Sep 9]. Available from: https://unhabitat.org/integratinghealth-in-urban-and-territorial-planning-a-sourcebook-forurban-leaders-health-and
8. Alfradique AM, Bonolo PF, Dourado I, Lima-Costa MF, Macinko J, Mendonça CS, et al. Internações por condições sensíveis à atenção primária: a construção da lista brasileira como ferramenta para medir o desempenho do sistema de saúde (Projeto ICSAP - Brasil). Cad Saude Publica. 2009;25:133749.

9. Harris JB, LaRocque RC, Qadri F, Ryan ET, Calderwood SB. Cholera. Lancet. 2012;379:2466-76.

10. Deen J, Mengel MA, Clemens JD. Epidemiology of cholera. Vaccine. 2020;38 Suppl 1:A31-40.

11. Bartram J, Cairncross S. Hygiene, sanitation, and water: forgotten foundations of health. PLoS Med. 2010;7:e1000367.

12. World Health Organization. Global report on urban health: equitable, healthier cities for sustainable development. Geneva: WHO; 2016. [cited 2020 Sep 9]. Available from: https://www. who.int/gender-equity-rights/knowledge/global-report-onurban-health/en/

13. Ross AG, Rahman M, Alam M, Zaman K, Qadri F. Can we 'WaSH' infectious diseases out of slums? Int J Infect Dis. 2020;92:1302.

14. The Lancet. Redefining vulnerability in the era of COVID-19. Lancet. 2020;395:1089.

15. Porto MF. Crise das utopias e as quatro justiças: ecologias, epistemologias e emancipação social para reinventar a saúde coletiva. Cienc Saude Coletiva. 2019;24:4449-58.

16. Associação Brasileira de Saúde Coletiva. "Enfoque foi inserir a iniciativa privada", aponta Léo Heller sobre PL 4162/19. Rio de Janeiro: ABRASCO; 2020 [cited 2020 Sep 9]. Available from: https://www.abrasco.org.br/site/noticias/enfoque-foi-inserir-ainiciativa-privada-aponta-leo-heller-sobre-pl-4162-19/49633/

17. Associação Brasileira de Saúde Coletiva. Água limpa e saneamento básico são direitos de todos e não mercadorias! Não ao PL 4162/19!. Rio de Janeiro: ABRASCO; 2020 [cited 2020 Sep 9]. Available from: https://www.abrasco.org. $\mathrm{br} / \mathrm{site} /$ noticias/ecologia-e-meio-ambiente/agua-limpa-e-osaneamento-basico-sao-direitos-de-todos-e-nao-mercadoriasnao-ao-pl-4162-19/49593/

18. Machado CV, Silva GA. Political struggles for a universal health system in Brazil: successes and limits in the reduction of inequalities. Global Health. 2019;15 Suppl 1:77.

19. United Nations. UN-Water Decade Programme on Advocacy and Communication. The human right to water and sanitation: milestones. [cited 2020 Sep 9]. Available from: https://www. un.org/waterforlifedecade/pdf/human_right_to_water_and_ sanitation_milestones.pdf

20. United Nations. Resolution adopted by the General Assembly on 28 July 2010: 64/292. The human right to water and sanitation. [cited 2020 Sep 9]. Available from: https://www.un.org/ga/ search/view_doc.asp?symbol=A/RES/64/292 